\title{
Mystery of Immune Response in Relapsed Brucellosis: Immunophenotyping and Multiple Cytokine Analysis
}

\author{
Relaps Brusellozda Immün Yanıtın Gizemi: Immünfenotipleme ve Çoklu Sitokin Analizi
}

\author{
Başak KAYHAN1, Üner KAYABAŞ², Servet KÖLGELIER33, Barış OTLU4, Mehmet GÜL5, Elçin Latife KURTOĞLU1, Yaşar BAYINDIR² \\ 1inönü University Faculty of Medicine, Department of Medical Biology and Genetics, Malatya, Turkey \\ 2Inönü University Faculty of Medicine, Department of Infectious Diseases and Clinical Microbiology, Malatya, Turkey \\ ${ }^{3}$ Adıyaman University Faculty of Medicine, Department of Infectious Diseases and Clinical Microbiology, Adıyaman, Turkey \\ 4 inönü Univeristy Faculty of Medicine, Department of Medical Microbiology, Malatya, Turkey \\ SInönü Univeristy Faculty of Medicine, Department of Histology and Embryology, Malatya, Turkey
}

\section{Abstract}

Introduction: Brucella spp. are intracellular bacteria that may cause acute, subacute and chronic infections. Despite optimum antibiotic treatment relapse of brucellosis occurs in some patients. There is less amount of knowledge about immune response in relapse of brucellosis.

Materials and Methods: Twenty patients with acute brucellosis, 16 patients with relapsed brucellosis and as a control group 20 healthy volunteers were enrolled in this study to explore the immune response variation during relapse of brucellosis. The distribution of peripheral blood mononuclear cells was investigated by flow cytometry and level of various cytokines involved in inflammatory and anti-inflammatory response were measured by enzyme-linked immunosorbent assay in serum samples.

Results: The most prominent data in phenotyping examination was the significant reduction (1.45 times) in the percentage of activated T cell (CD3+human leukocyte antigen-DR+) population in the relapse group in comparison to the acute brucellosis group. However, percentage of activated T cell population in the relapse group was 2.59 times higher than in healthy controls $(p<0.01)$. We observed a significant reduction in inflammatory cytokines interleukin (IL)-6, IL-18, interferon- $\gamma$ and IL-17 in relapsed patients in comparison to patients with acute brucellosis. While there was no significant difference in IL-15 and tumor necrosis factor- $\alpha$ levels between relapse and acute brucellosis groups, the levels of these two cytokines were significantly higher in the relapse group than in healthy subjects. In case of anti-inflammatory cytokines, while IL-4 levels increased significantly only in relapse group, IL-10 levels increased both in acute and relapse brucellosis group in comparison to healthy controls. Interestingly, we observed 2.87 times elevation in IL-4 levels in the relapse group in comparison to acute brucellosis ( $<<0.01)$. Similarly; IL-10 levels increased 2.09 times in patients with relapsed brucellosis patients in comparison to acute brucellosis ( $p<0.01)$.

Conclusion: Elevation of regulatory cytokines in systemic immune system and reduction of activated T cell frequency occur during the relapse of brucellosis. These results may contribute to understanding the immunopathology in the systemic circulation during relapse of brucellosis.

Keywords: Brucellosis, cytokines, immune response, relapse, tumor necrosis factor alpha

Öz

Giriş: Brucella spp., akut, subakut ve kronik enfeksiyonlara neden olabilen hücre içi bakteridir. Optimum antibiyotik tedavisine rağmen, bazı hastalarda brusellozun relapsı ortaya çıkmaktadır. Brusellozun relapsındaki immün yanıt hakkında çok az bilgi bulunmaktadır.

Gereç ve Yöntem: Bu çalışmada, brusellozun relapsı esnasındaki immün yanıt değişimlerini araştırmak için akut brusellozlu yirmi hasta, relaps brusellozlu on altı hasta ve kontrol grubu olarak 20 sağlıklı gönüllü kaydedilmiştir. Periferik kan mononükleer hücrelerin dağılımı akım sitometri ile araştırılmıştır ve enflamatuvar ve anti-enflamatuvar yanıtta işe karışan çeşitli sitokin seviyeleri serum örneklerinde dolaylı enzime-bağlı bağışıklık deneyi ile ölçülmüştür.

Bulgular: Fenotipleme araştırmasında en dikkat çeken veri; akut brusellozla karşılaştırıldığında relaps grubundaki aktive olmuş T hücre (CD3+insan lökosit antijeni-DR+) yüzdesindeki 1,45 kat anlamlı azalmaydı. Ancak, relaps grubundaki aktive olmuş T hücre popülasyonunun yüzdesi sağlıklı gruptan 2,59 kat daha yüksekti $(p<0,01)$. Diğer taraftan, akut brusellozlu hastalarla karşılaştırıldığında relaps olmuş hastalardaki interlökin (IL)6, IL-8, interferon- $\gamma$ ve IL-17 enflamatuvar sitokinlerde anlamlı azalma gözlemledik. Relaps ve akut bruselloz grupları arasında IL-15 ve tümör nekroz faktör- $\alpha$ seviyelerinde anlamlı fark bulunmazken, relaps grubunda bu iki sitokinin seviyesi sağlıklı örneklere göre anlamlı bir biçimde daha 
yüksekti. Anti-enflamatuvar sitokinler bakımından IL-4 düzeyi sadece relaps grubunda belirgin düzeyde artarken, IL-10 düzeyi hem akut, hem de sağlıklı bireylerde kontrol grubuna göre belirgin düzeyde yüksekti. İlginç bir şekilde, akut bruselloz ile karşılaştırıldığında relaps grubundaki IL-4 seviyelerinde 2,87 kat yükselme gözlemlendi $(p<0,01)$. Benzer şekilde, IL-10 seviyeleri de akut bruselloz hastaları ile karşılaştırıldığında relaps olmuş brusellozlu hastalarda 2,09 kat artmıştı $(p<0,01)$.

Sonuç: Regülatör sitokinler sistemik immün sistemde yüksektir ve brusellozun relapsı esnasında azalmış aktive T hücre sıklığı ortaya çıkmaktadır. Bu sonuçlar brusellozun relapsı esnasındaki sistemik dolaşımdaki immünopatolojiyi anlamada öneme sahip olabilir.

Anahtar Kelimeler: Bruselloz, sitokinler, immün yanıt, relaps, tümör nekroz faktör alfa

\section{Introduction}

Brucella spp. are Gram-negative, facultative intracellular bacteria that cause acute and chronic brucellosis, a zoonotic disease. Consumption of contaminated food, especially unpasteurized milk and dairy products and, more rarely, occupational exposure may result in infection in humans. It is not only a huge economic burden in developing countries, but also a potential bio-terrorism agent in the United States since it is a class 3 pathogen ${ }^{[1-3]}$. Historically, only Brucella melitensis, $B$. abortus, $B$. suis and $B$. canis were considered human pathogens, however, the majority of human diseases are caused by $B$. melitensis and B. abortus ${ }^{[1,4]}$. Similarly, infections caused by different Brucella spp. have been shown in different reports. De et al. ${ }^{[5]}$ reported an infection caused by $B$. inopinata in a patient with prosthetic breast implants, and humans infected with a murine strain, $B$. ceti, have been reported ${ }^{[5-7]}$.

Brucellosis is a systemic disease involving any organ or system in some mammals. Bacteria create a unique intracellular niche in macrophages, which causes granulomatous infection and requires combined protracted antibiotic treatment in humans. Additionally, the presence of neutrophilic infiltrates have been reported and can cause a necrotizing inflammatory response, such as arthritis, meningitis, peritonitis, and abscesses in different human organs and placentitis in some mammals ${ }^{[8-10]}$. The clinical forms of human brucellosis are determined according to the duration of symptoms and are described as acute (less than 8 weeks), subacute (from 8 to 52 weeks) and chronic (more than one year). The immune response varies according to the clinical forms ${ }^{[1,8,11,12]}$. In acute brucellosis, overproduction of $\mathrm{T}$ helper-1 (Th1) cytokines, primarily interferon-gamma (IFN- $\gamma$ ) and interleukin (IL)-2, has been detected in serum samples and in the intracytoplasmic niche. Adequate antibiotic treatment reduces or normalizes these levels. However, in chronic brucellosis, detection of lower $\mathrm{CD}^{+} \gamma^{+}$levels prior to antibiotic treatment indicates a defective Th1 response. This defect causes an imbalance between Th1 and T helper-2 (Th2) T cell responses. It is estimated that the diminished production of Th1 cytokines in these patients occurs because of the Th2 switch to and/or the release of immune-regulatory cytokines, such as TGF- $\beta 1^{[12,13-15]}$.

In case of relapsed brucellosis, there is less amount of knowledge about the type and kinetics of the immune response. The cause of relapse in brucellosis can be either a lack of an immunological response or a genetic deficiency. To understand the differences in immune responses during the relapsed brucellosis compared with acute brucellosis and healthy volunteers, we investigated the type of immune cells in systemic circulation using immunophenotyping of peripheral blood samples. Furthermore, we analyzed the levels of inflammatory and anti-inflammatory cytokines in peripheral blood circulation.

\section{Materials and Methods}

\section{Ethics and Study Population}

The study was approved by the local Ethics Committee for human clinical investigations, which conforms to protocols in accordance with the Declaration of Helsinki (form number 2011/19). All participants were volunteers and provided written informed consent.

Twenty patients with acute brucellosis (nine men and 11 women, mean age: 37 years, range: 19-55 years) and 16 patients with relapsed brucellosis (nine men and seven women, mean age: 40 years, range: $22-56$ years) were enrolled in the study.

Acute brucellosis was defined as the presence of consistent signs and symptoms of brucellosis for less than eight weeks along with the presence of one of the following: serum Brucella agglutination titer $\geq 1 / 160$ or isolation of Brucella spp., either from the blood or other clinical sample ${ }^{[1]}$. Relapse was defined as the reappearance of symptoms or signs of the disease assessed by a physician, or a new positive blood culture, or demonstration of specific immunoglobulin $\mathrm{G}(\mathrm{IgG})$ rising by Brucella tube agglutination test with 2-mercaptoethanol-result within the 12-month period after the end of therapy ${ }^{[16]}$. Data were collected until time of relapse or conclusion of the trial, whichever came first. All blood samples were obtained before antibiotic treatment in acute and relapsed brucellosis groups.

The controls were selected from 20 age-matched healthy volunteers (nine men and 11 women, mean age 37 years, range 28-52 years) who were not having common infectious diseases or any chronic or autoimmune disorders and were negative for brucellosis according to serologic tests and clinical data. Female volunteers were not pregnant.

\section{Measurement of Cytokines}

Inflammatory cytokines, IL-15 (Immunoleader, Boster Biological Technology, Pleasanton, CA), IL-17 and IL-18 (eBioscience, 
Bender Medsystems, Vienna, Austria) were measured by enzymelinked immunosorbent assay according to the manufacturer's instructions. The inflammatory cytokines IL-6, IFN- $\gamma$, tumor necrosis factor (TNF)- $\alpha$, and anti-inflammatory cytokines IL-4 and IL-10 were measured by FlowCytomix bead assay (BenderMed Systems, GmbH, Vienna, Austria) using flow cytometry as described previously ${ }^{[17]}$. Briefly; serum samples or serially diluted standards were resuspended with fluorescent beads coated with monoclonal antibodies specific to the cytokines together with biotin-conjugated monoclonal antibodies specific for each cytokine in 96-well plates. Following that, the beads were incubated with phycoerythrin (Pe)-labeled streptavidin. fluorescent sensor 4 with $675 \mathrm{~nm}$ detector was used to analyze and quantitate beads. Standard curves were determined for each cytokine from a range of $27-20.000 \mathrm{pg} / \mathrm{mL}$. Samples and standards were analyzed with a FACSCanto ${ }^{\mathrm{TM}}$ II flow cytometer (BD BioScience San Jose, CA, USA). The concentrations were measured by using the FlowCytomix Pro 2.2 software (Bender Med Systems). For each analysis, 10.000 beads were collected.

\section{Flow Cytometry Analysis}

Mouse anti-human monoclonal antibodies specific for $\lg _{1,2 a^{\prime}}$ CD14, CD45, CD3, CD19, CD4, CD8, human leukocyte antigen (HLA)-DR, and CD16 $56^{+}$were purchased from BD Bioscience (San Jose, CA, USA). Peripheral blood lymphocyte phenotypes

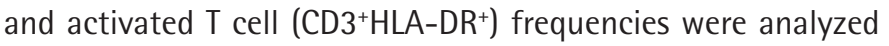
following an immunofluorescence procedure described previously. Anti-human monoclonal antibodies specific for $\lg _{1,2 a}$ were used as a negative control to detect non-specific binding. Briefly, peripheral blood samples were incubated with $10 \mathrm{ml}$ fluorescein isothiocyanate- or Pe-labeled mouse antihuman monoclonal antibodies in the dark for 30 minutes at $4{ }^{\circ} \mathrm{C}^{[18]}$. Then, the erythrocytes were lysed in BD FACS Lysis solution according to the manufacturer's instructions. A BD BioScience FACSCanto ${ }^{\mathrm{TM}}$ II six-color flow cytometer equipped with the computer software FASC Diva (BD BioScience, USA) was used to assess the phenotype of the mononuclear cells. For each analysis, 20.000 cells were collected. The percent of positive cells obtained according to gating with isotype control for each sample.

\section{Statistical Analysis}

Statistical analysis was performed using the Statistical Package for the Social Sciences 10.0 (SPSS 10.0) (SPSS Inc., Chicago, USA) software. The results of continuous variables are presented as mean values with standard deviations. A comparison of continuous variables among groups was performed using Student's $t$ test for variables with a normal distribution and the Mann-Whitney $U$ test for variables with a non-normal distribution. Normality for continuous variables in groups was determined using the Kolmogorov-Smirnov test. Additionally,
Pearson's correlation coefficient was used to analyze the relationship between two parametric variables, and $p$ values $<0.05$ were considered statistically significant.

\section{Results}

Blood culture tests were performed in 14 of 20 acute brucellosis patients and 10 of them were positive. In case of relapsed brucellosis, blood culture tests were performed in 12 of 16 patients and two of them were positive.

\section{Phenotype Distribution of Peripheral Blood Mononuclear Cells}

Before analyzing the lymphocytes and sub-type of lymphocytes in the peripheral blood, granulocytes and lymphocytes were separated with different gates as shown in Figure 1. Since the monocyte population was dragged through granulocyte population in several samples of the acute and relapsed brucellosis groups based on flow cytometry, it was difficult to separate monocytes from granulocytes by using forward and side scatter analysis only. Therefore, monocytes were identified by using anti-CD14 monoclonal antibody as shown in Figure 2A, 2B. We did not observe a significant difference in ratio of CD14 population between healthy group and brucellosis groups.

Since B-lymphocytes provide an infectious niche for Brucella spp. ${ }^{[19]}$; investigating the frequency of $\mathrm{CD} 19^{+} \mathrm{B}$ cell population makes sense to understand the immunopathology of brucellosis. As shown in Figure $2 \mathrm{~B}$, we did not observe a significant difference in percentage of $\mathrm{CD} 19^{+} \mathrm{B}$ cell population between the three groups.

Patients with acute brucellosis had a significantly higher percentage of $\mathrm{CD}^{+} \mathrm{T}$ lymphocytes compared with healthy

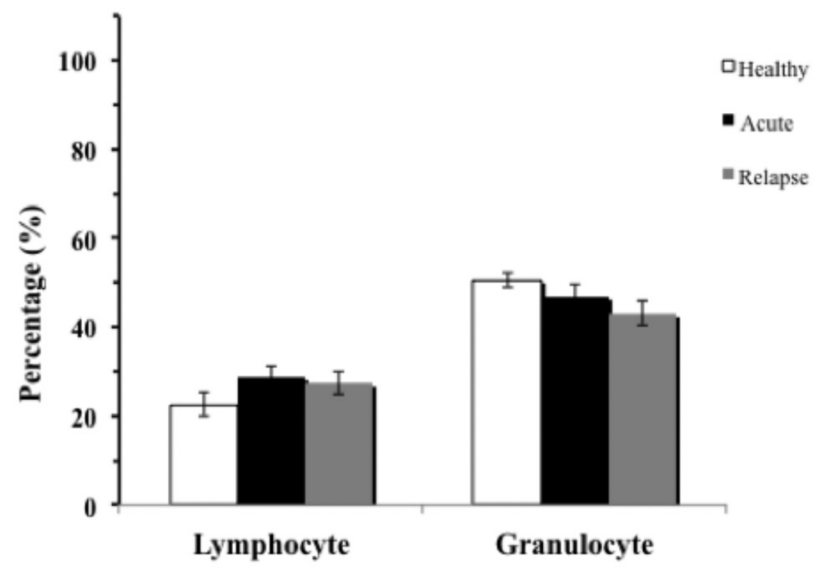

Figure 1. Distribution of lymphocytes and granulocytes in peripheral blood samples of healthy (white bar), acute brucellosis (black bar) and relapsed brucellosis patients (grey bar). According to forward and side scatter analysis in flow cytometry, the mean percentages of lymphocytes and granulocytes were calculated. Data are shown as the mean \pm standart error. 
individuals and relapse patients $(p<0.001$ and $p=0.01$, respectively) (Figure 3). The analysis of the T-lymphocyte subgroups showed a significant reduction in $\mathrm{CD}^{+}{ }^{+} \mathrm{T}$ cell frequency in relapsed brucellosis patients compared with the acute brucellosis group $(p=0.028)$ (Figure 3$)$. We observed a significant increase in $\mathrm{CD}^{+} \mathrm{T}$ cell frequency in acute and relapsed brucellosis compared with the healthy group $(p<0.05)$ (Figure 3). Furthermore, the CD4/CD8 ratio was significantly increased toward to $\mathrm{CD} 8^{+} \mathrm{T}$ cells only in the relapsed brucellosis group compared with the healthy individuals $(p<0.001)$ (Table 1$)$.
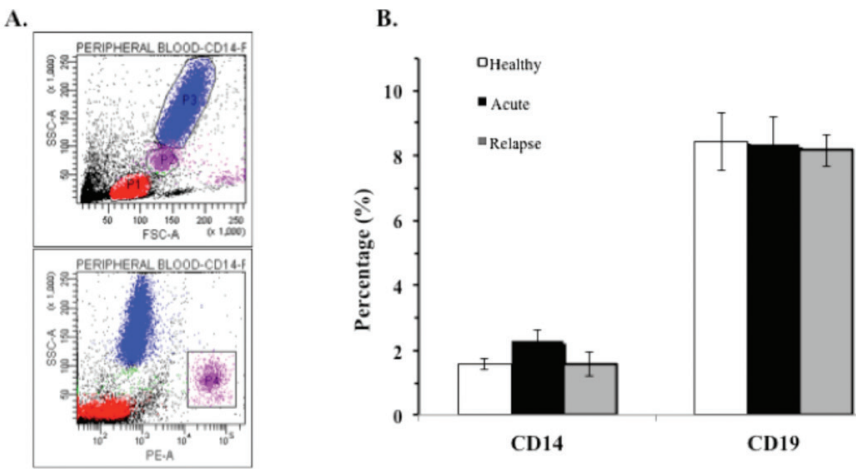

Figure 2. CD14+ monocytes population was presented among peripheral blood cells. A) Is a representative flow cytometry diagram of a peripheral blood sample from an acute brucellosis patient. B) Shows the percentages of CD14+ and CD3-/CD19+ B-lymphocyte populations among lymphocyte gate. Data are shown as the mean \pm standart error.

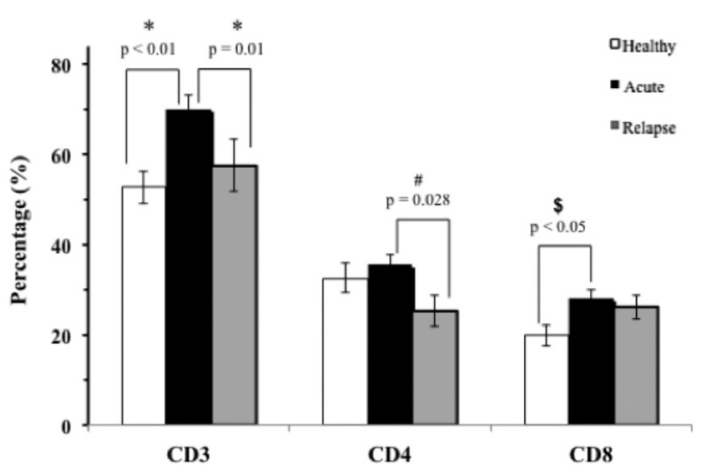

Figure 3. Immunophenotyping profile of peripheral blood lymphocytes $\mathrm{T}^{-}\left(\mathrm{CD} 3^{+} / \mathrm{CD}^{-} 9^{-}\right)$were presented among lymphocyte gate and $\mathrm{T}$ helper cells $\left(\mathrm{CD} 3+\mathrm{CD}^{+}\right)$and cytotoxic $\mathrm{T}$ cells $\left(C D 3+C D 8^{+}\right)$percentages were presented after gating among CD3+ T-lymphocytes. Data are shown as the mean \pm standart error.

*Indicates statistical significance of CD3 T cell percentage in acute brucellosis patients in comparison to healthy $(p<0.001)$ and relapsed $(p=0.01)$ group. \#Indicates statistical difference between acute and relapsed groups. \$Indicates statistical difference of $\mathrm{CD} 8+\mathrm{T}$ cell percentage in healthy individuals in comparison to acute $(p=0.009)$ and relapse brucellosis patients $(p=0.005)$
Activated T cells were defined as the CD3 ${ }^{+} H L A-D R^{+}$population in peripheral blood samples ${ }^{[20]}$. During acute brucellosis, the percentage of activated $T$ cells increased significantly compared with the healthy and relapsed brucellosis groups (Figure 4A, $4 B, p<0.01$ and $p=0.01$, respectively). Although in the relapse group the percentage of activated T cells decreased, it did not reach the levels in the healthy group and was still significantly higher than healthy controls (Figure 4A, 4B) $(p<0.01)$. We also determined whether that elevation correlated with the titer values of the agglutination tests or not. We did not observe any correlation between these two variables $(p>0.05$ for both variables) ( $r=0.430$ and $r=0.260$ for acute and relapsing brucellosis groups, respectively).

Other lymphoid group members, natural killer (NK) and NK-T lymphocytes, which are phenotypically and functionally distinct from B and T lymphocytes, were investigated. NK cells were identified as $\mathrm{CD} 3^{-} \mathrm{CD} 16^{+} \mathrm{CD} 56^{+}{ }^{[21]}$ and NK-T cells were identified as $\mathrm{CD}^{+}{ }^{+} \mathrm{CD} 16^{+} \mathrm{CD} 56^{+}$. We did not observe significant differences in the frequency of NK and NK-T cells between the three groups (Table 1).

\section{Inflammatory and Anti-inflammatory Cytokine Levels}

For inflammatory cytokines, we analyzed the cytokines responsible from innate immune response IL-6, TNF- $\alpha$, IL-15 and the cytokines responsible from adaptive immune response IFN- $\gamma$, IL-17, IL-18 in all samples. Acute brucellosis induced a significant increase in IL-6 and TNF- $\alpha$ compared with healthy individuals ( $p=0.001$ for IL-6 and $p<0.001$ for TNF- $\alpha$ ) (Figure $5 A, 5 B$, respectively). As shown, relapsed brucellosis patients

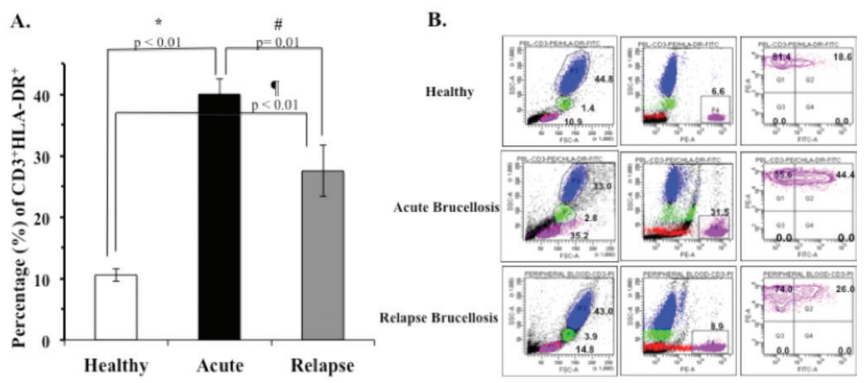

Figure 4. A, B) Distribution of activated T cells in peripheral blood samples of healthy (white bar), acute (black bar) and relapsed (grey bar) brucellosis patients. Activated T cells were identified as CD3+human leukocyte antigen-DR+ $T$ cells in flow cytometry analysis. CD3+human leukocyte antigen-DR+ activated $\mathrm{T}$ cells were analyzed after gating CD3+ T cells in lymphocyte gate. Data are presented as the mean value of percentages \pm standart error.

*Indicates statistical significance of activated T cell level in acute brucellosis in comparison to healthy group. \#indicates significant difference between relapsed and acute brucellosis groups. "Represents the significant difference between relapsed brucellosis and healthy groups (A). Representative flow cytometry analysis of activated T cells from healthy, acute brucellosis, relapsed brucellosis groups were presented (B).

HLA: Human leukocyte antigen 
had significantly lower IL-6 levels compared to those with acute brucellosis (Figure 5A). We observed a significant increase in TNF- $\alpha$ levels in acute and relapsed brucellosis patients compared with healthy individuals $(p<0.001)$ (Figure $5 B$ ). We did not observe a reduction in IL-15 levels in relapsed patients, a cytokine that induces the proliferation of NK cells and promotes the innate and adaptive immune responses. The IL-15 levels were significantly higher in the relapsed group than in healthy individuals (Figure $5 C)(p=0.002)$. However, this increase was not significant when compared with the acute brucellosis group ( $>0.05)$.

Acute brucellosis induced a significant increase in IFN- $\gamma$ and IL-17 levels compared with healthy individuals. Interestingly, IFN- $\gamma$ and IL-17 levels in relapsed brucellosis patients were significantly lower than in acute brucellosis patients $(p<0.001)$ (Figure 5D, 5E). However, IFN- $\gamma$ levels in the relapsed brucellosis group were significantly higher than in healthy individuals group ( $p=0.014$ ) but statistical significance was not reached for IL-17 levels in relapsed brucellosis vs healthy subjects.
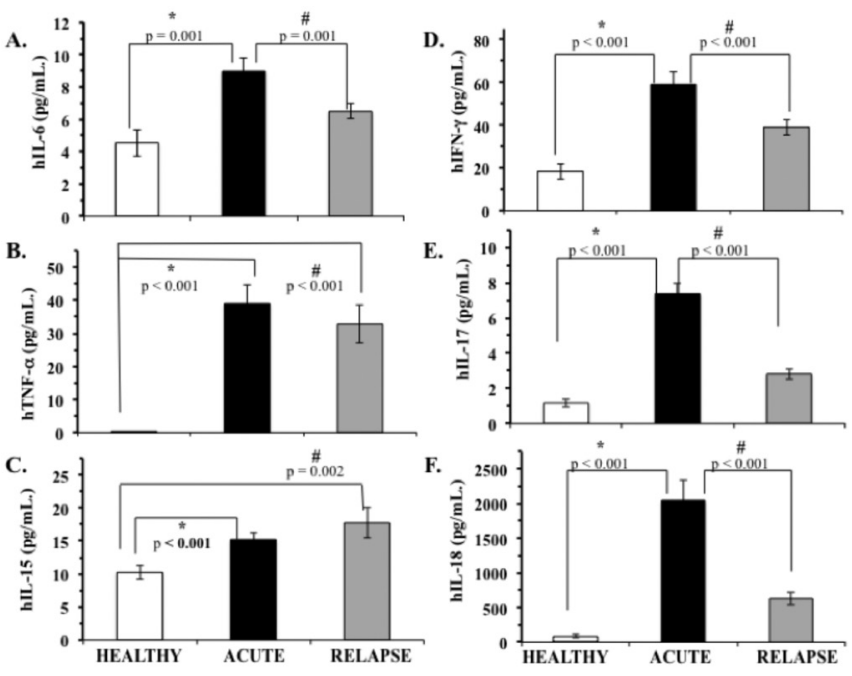

Figure 5. A-F) Concentrations of inflammatory cytokines role in innate immune response IL-6 (A), TNF- $\alpha(B), I L-15$ (C) and role in adaptive immune response $\gamma(\mathrm{D}), \mathrm{IL}-17$ (E), IL-18 (F) in peripheral blood serum samples of healthy (white bar) donors, acute (black bar) and relapsed (grey bar) brucellosis patients. Data are shown as mean values of 20 healthy donors, 20 acute and 16 relapsed brucellosis patients \pm standart error.

* and \# symbolize statistical difference between mentioned groups
Acute brucellosis induced a significant elevation in IL-18 level in serum samples in comparison to healthy objects. That elevation reached to 3.2 times in acute brucellosis group in comparison to relapse group $(p<0.001)$ (Figure $5 F)$.

An opposite effect was observed for the anti-inflammatory cytokines IL-4 and IL-10 (Figure 6A, 6B). Acute brucellosis did not induce a significant increase in IL-4 compared with healthy individuals. For IL-10, we observed a significant increase of IL10 in the serum samples of acute brucellosis patients compared with healthy individuals $(p=0.007)$. There was a significant elevation of both IL-4 and IL-10 levels in patients with relapsed brucellosis when compared to acute patients $(p<0.001$ for IL-4 and IL-10).

\section{Discussion}

The clinical forms of human brucellosis are determined according to the duration of symptoms as acute, sub-acute

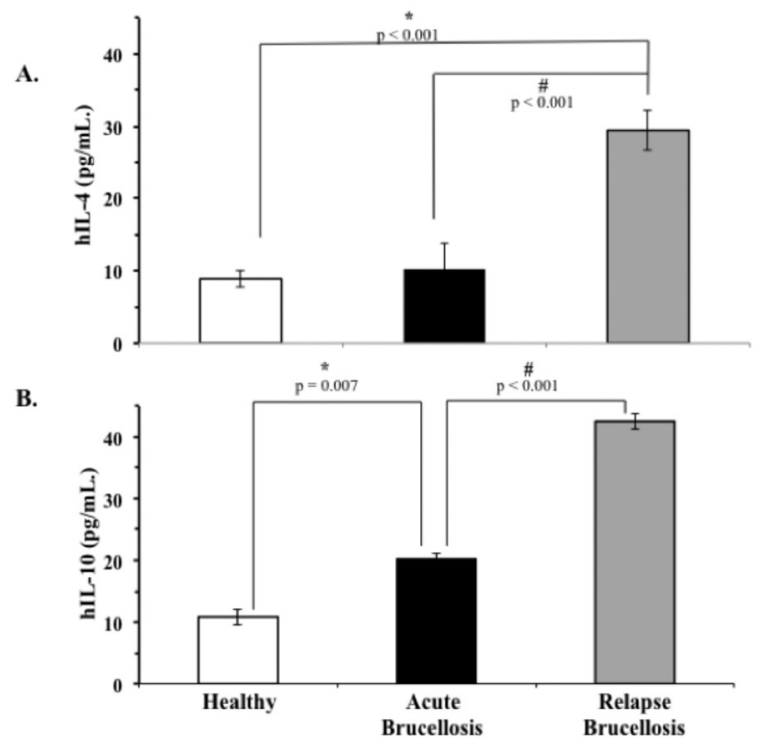

Figure 6. A, B) Concentrations of anti-inflammatory cytokines interleukin (IL)-4 (A) and IL-10 (B) in peripheral blood serum samples of healthy (white bar) donors, acute (black bar) and relapsed (grey bar) brucellosis patients. Data are shown as mean values of 20 healthy donors, 20 acute and 16 relapsed brucellosis patients \pm standart error.

${ }^{*}, \#$ and $\$$ symbolize statistical difference between mentioned groups

Table 1. Comparison of CD4/CD8 ratio and percentages (\%) of natural killer (NK) and NK-T cells in peripheral blood samples of healthy individuals, acute and relapse brucellosis subjects. NK cells were determined as CD3-CD16+CD56+/-; NK-T cells were determined as CD3 + CD $16+C D 56+/-$ in flow cytometry analysis. Results are presented as mean \pm standard deviation.

\begin{tabular}{l|l|l|l}
\hline Population & Healthy $(\mathbf{n}=\mathbf{2 0})$ & Acute brucellosis $(\mathbf{n}=\mathbf{2 0})$ & Relapse brucellosis $(\mathbf{n}=\mathbf{1 6})$ \\
\hline CD4/CD8 ratio & $1.82 \pm 0.179$ & $1.39 \pm 0.136$ & $1.11 \pm 0.180^{*}$ \\
\hline NK cells & $9.96 \pm 1.27(\%)$ & $8.35 \pm 0.75(\%)$ & $7.42 \pm 0.63(\%)$ \\
\hline NK-T cells & $4.96 \pm 0.93(\%)$ & $6.28 \pm 1.52(\%)$ & $6.96 \pm 2.01(\%)$ \\
\hline
\end{tabular}

*Symbolizes the significant difference between relapse brucellosis and healthy groups ( $p<0.001)$, NK: Natural killer 
and chronic. Although adequate antibiotic treatment reduces or normalizes immunpathological view of these clinical forms, it is not known why brucellosis causes relapse in some patients. Is that because of a genetic deficiency in the host or a defect in a part of immune response? In this study, we investigated the latter possibility by phenotyping the immune cells and measuring the levels of inflammatory and anti-inflammatory cytokines in systemic circulation.

In this study; a significant reduction in the percentages of activated $\mathrm{T}$ lymphocytes, resembling an anti-inflammatory immune response, with high concentrations of IL-4 and IL-10 in the peripheral blood of relapsed brucellosis patients were detected when compared with acute brucellosis patients.

Host protection against Brucella spp. depends on cell-mediated immunity, including activated macrophages, dendritic cells and activated T cells. The T helper 1 (Th1) immune response and the production of IFN- $\gamma$ from these cells are essential for the clearance of Brucella infection in humans. Koçoğlu et al. ${ }^{[2]}$ demonstrated a significant increase in circulating activated $T$ cell numbers $\left(\mathrm{CD}^{+}{ }^{+} \mathrm{HA}-\mathrm{DR}{ }^{+}\right)$without significant alterations in the subpopulations of peripheral blood lymphocytes in acute brucellosis patients. Brucella spp. avoid or manipulate host immunity for their own benefit, and according to our findings, in the case of relapse, there is a decrease in the frequency of both $\mathrm{CD} 4^{+} \mathrm{T}$ cells and activated $\mathrm{T}$ cells $\left(\mathrm{CD} 3^{+} \mathrm{HLA}-\mathrm{DR}^{+}\right)$in the peripheral blood. Chronic brucellosis patients display a defective Th1 response and a decreased percentage of $C D 4^{+} \mathrm{T}$ cells expressing $C D 25^{[22,23]}$. We hypothesize that the suppression of naïve or activated T cells or a defective Th1 response are either a function of regulatory $\mathrm{T}$ (Treg) cells or suppressor T cells, which leads to the progression of infection both in relapse and chronic brucellosis patients. Corresponding with the phenotypic observations, the limited expansion of $\mathrm{CD}^{+} \mathrm{T}$ cells affects the production of inflammatory cytokines in the Th1 and Th17 T cell groups. However, the significant decrease in IFN- $\gamma$ and IL-17 levels and the significant increase in IL-10 in relapse patients suggest a change in the frequency of Treg cells during brucellosis relapse compared with acute brucellosis. Pasquali et al. ${ }^{[2]}$ observed that Treg cells suppress the effector functions of $\mathrm{CD}^{+}{ }^{+}$ T cells in infected mice, and they showed that Treg cells allow the expansion of brucellosis. In a clinical investigation, Skendros et al. ${ }^{[23]}$ observed that chronic brucellosis patients retain low percentages of $\mathrm{CD}^{+} \mathrm{CD} 25^{+}$and $\mathrm{CD}_{4}^{+} \mathrm{CD} 28^{+} \mathrm{T}$ lymphocytes after potent stimulation with phytohemagglutinin-cultured peripheral blood cells using Escherichia coli lipopolysaccharide (LPS). Accordingly, they concluded that Brucella spp. modulate the functional arms of the human immune system.

Similar to the observations of Çelik and Akbulut, ${ }^{[21]}$ we determined that the $C D 8^{+} \mathrm{T}$ cell population increases in acute patients compared with healthy subjects. Interestingly, that elevation also occurs in relapse patients. Unfortunately, we do not know whether these $C D 8^{+} T$ cells are functional and whether their expansion is limited or not. Therefore, further studies are necessary on that case. Besides, Skendros et al. ${ }^{[25]}$ observed a significant elevation in $\mathrm{CD}^{+} \mathrm{T}$ cell population in chronic brucellosis patients and also in relapsed chronic brucellosis patients in comparison to acute brucellosis. They concluded that, elevation of $\mathrm{CD}^{+} \mathrm{T}$ cell population in peripheral blood mononuclear cells of chronic brucellosis and relapsed patients probably compensates ineffectual $C D 4^{+} T$ cell response in chronic brucellosis patients.

Brucellosis causes a Th1-type inflammatory response and induces the production of inflammatory cytokines during acute infection. The majority of studies indicate that the major source of IFN- $\gamma$ is $C D 4^{+} T$ cells, however, $C D 8^{+} T$ cells, $\gamma \delta$ T cells and NK cells also produce IFN- $\gamma^{[2,27]}$. Interestingly, during relapse of brucellosis, we observed a significant decrease in inflammatory cytokines, except for TNF- $\alpha$ and IL-15, in the systemic circulation. Recently, Feldman et al. ${ }^{[28]}$ performed an ex vivo study to measure the expression and secretion of several inflammatory cytokines in peripheral blood mononuclear cells after stimulation with LPS or heat-killed B. melitensis (HKBM). They concluded that acute and relapse patients were largely identical by their cytokine gene expression profiles, however, there was a strong cytokine secretion that accurately discriminates acute from relapse patients which may allow for better follow up care of brucellosis patients through improved identification of patients at risk of relapse. We have found several similar results to those of Feldman et al.. ${ }^{[28]}$ particularly in the case of TNF- $\alpha$ levels, in which they observed higher expression after LPS stimulation compared with both acute brucellosis and control donors. They also observed increased IFN- $\gamma$ expression after HKBM stimulation in relapse patients and concluded that relapse of brucellosis in patients can induce the expression of cytokines necessary to mount a Th1 response. However, they found increased IL-10 gene expression after stimulation with HKBM in both acute and relapsed brucellosis patients. The main question that remains unanswered is, 'Does the relapse of brucellosis cause an inflammatory or anti-inflammatory immune response?' It has been observed that protective immunity against $B$. abortus was down-regulated by IL-10, and the dominant Th1 cytokine production switched towards Th2 cytokine production during long term of the disease ${ }^{[29,30]}$.

According to our data, a reduction of inflammatory cytokines in relapsed patients is related to increases in immune suppressor cytokines, such as IL-10 and IL-4, which down-regulate the inflammatory immune response and the number of activated $\mathrm{T}$ cells. We propose several explanations for this type of down regulation of the inflammatory immune response. One is related to the expansion of Treg cells, and the second is Brucella- 
acquired cellular anergy. Accordingly, Pasquali et al. ${ }^{[23]}$ observed that $\mathrm{CD} 4^{+} \mathrm{CD} 25^{+}$Treg cells were responsible for the maintenance and progression of $B$. abortus infection in mice. Moreover, Xavier et al. ${ }^{[31]}$ showed that the persistent intracellular pathogen B. abortus prevents the immune activation of macrophages by inducing production of an anti-inflammatory cytokine IL-10 from $C D 4^{+} C D 25^{+} T$ cells during early infection time point that modulates macrophage function and contributes to an initial balance between pro-inflammatory and anti-inflammatory cytokines which is beneficial to the pathogen, thereby promoting enhanced bacterial survival. Anergy occurs primarily in chronic brucellosis patients, which represent approximately $10 \%$ to $30 \%$ of brucellosis patients. It is predicted that patients with chronic brucellosis display defective Th1 responses and T cell anergy, which is identified by decreased Th1 cytokine production by peripheral blood cells, increased proportion of CD8 cells in the CD4/CD8 ratio, reduced CD69+ early activated T lymphocytes, and low proliferative responses of lymphocytes to mitogens or Brucella antigens ${ }^{[11,12]}$.

Whether or not all intracellular bacteria cause a regulatory immune response during relapse of disease is not known. Tuberculosis, caused by intracellular bacteria, may relapse after primary disease. de Steenwinkel et al. ${ }^{[32]}$ compared the cytokine response of immune system in relapsed tuberculosis patients with primary disease patients. They observed that; levels of TNF- $\alpha$, IFN- $\gamma$, IL-6, and IL-17 were significantly lower in relapsed tuberculosis patients in comparison to in those with primary tuberculosis. In contrast to our observation in relapse of brucellosis; they observed that in relapse of tuberculosis, memory Th1 cells locally and systemically expanded and congregated in lung, permitting an efficient control of Mycobacterium tuberculosis growth.

\section{Conclusion}

In conclusion, during relapse of brucellosis, CD4/CD8 ratio decreased and regulatory cytokines were dominant in the systemic immune system. Additionally, activated T cell frequency decreased during the relapse of brucellosis. Determining triple cytokine (IL-4, IL-10 and IFN- $\gamma$ ) levels may be beneficial to follow up acute and relapsed brucellosis patients. These results may contribute to understanding the immunopathology in the systemic circulation during brucellosis relapse.

\section{Ethics}

Ethics Committee Approval: This study has been approved by a Local Ethics Committee (form number 2011/19), Informed Consent: A consent form was filled out by all participants.

Peer-review: Externally and internally peer-reviewed.

\section{Authorship Contributions}

Surgical and Medical Practices: Yaşar Bayındır, Üner Kayabaş, Servet Kölgelier, Concept: Başak Kayhan, Yaşar Bayındır, Üner Kayabaş, Servet Kölgelier, Design: Başak Kayhan, Yaşar Bayındır, Data Collection of Processing: Başak Kayhan, Barış Otlu, Mehmet Gül, Elçin Latife Kurtoğlu, Analysis or Interpretation: Başak Kayhan, Yaşar Bayındır, Üner Kayabaş, Literature Search: Başak Kayhan, Yaşar Bayındır, Üner Kayabaş, Writing: Başak Kayhan, Yaşar Bayındır.

Conflict of Interest: No conflict of interest was declared by the authors.

Financial Disclosure: This study was granted by İnönü University Scientific Investigation Fund-2011/176.

\section{References}

1. Doganay M, Aygen B. Human brucellosis: an overview. Int J Infect Dis. 2003;7:173-82.

2. Pappas G, Akritidis N, Bosilkovski M, Tsianos E. Brucellosis. N Engl J Med. 2005;352:2325-36.

3. Doganay GD, Doganay M. Brucella as a potential agent of bioterrorism Recent Pat Antiinfect Drug Discov. 2013;8:27-33.

4. Franco MP, Mulder M, Gilman RH, Smits HL. Human brucellosis. Lancet Infect Dis. 2007;7:775-86.

5. De BK, Stauffer L, Kaylass MS, Sharp SE, Gee JE, Helsel LO, Steigerwalt AG, Vega R, Clark TA, Daneshvar MI, Wilkins PP, Whatmore AM. Novel Brucella strain (B01) associated with a prosthetic breast implant infection. J Clin Microbiol. 2008;46:43-9.

6. Brew SD, Perrett LL, Stack JA, Macmillan AP, Staunton NJ. Human exposure to Brucella recovered from a sea mammal. Vet Rec. 1999;144:483.

7. Sohn AH, Probert WS, Glaser CA, Gupta N, Ballen AW, Wong JD, Grace EM, McDonald WC. Human neurobrucellosis with intracerebral granuloma caused by a marine mammal Brucella spp. Emerg Infect Dis. 2003;9:485-8.

8. Xavier MN, Paixao TA, den Hartigh AB, Tsolis RM, Santos RL. Pathogenesis of Brucella spp. Open Vet Sci J. 2010;4:109-18.

9. Zwerdling A, Delpino MV, Pasquevich KA, Barrionuevo P, Cassataro J, Garcia Samartino C, Giambartolomei GH. Brucella abortus activates human neutrophils. Microbes Infect. 2009;11:689-97.

10. Anderson TD, Mealor VP, Cheville NF. Pathogenesis of placentitis in the goat inoculated with Brucella abortus. I. Gross and histologic lesions. Vet Pathol.1986;23:219-26.

11. Skendros P, Pappas G, Boura P. Cell-mediated immunity in human brucellosis. Microbes Infect. 2011;13:134-42.

12. Skendros P, Boura P. Immunity to brucellosis. Rev Sci Tech Off. 2013;32:137-47.

13. Akbulut HH, Kilic SS, Bulut V, Ozden M. Determination of intracellular cytokines produced by Th1 and Th2 cells using flow cytometry in patients with brucellosis. FEMS Immunol Med Microbiol. 2005;45:253-8.

14. Elfaki MG, Al-Hokail AA. Transforming growth factor $b$ production correlates with depressed lymphocytes function in humans with chronic brucellosis. Microbes Infect. 2009;11:1089-96.

15. Rodriguez-Zapata M, Matias MJ, Prieto A, Jonde MA, Moserrat J, Sanchez L, Reyes E, De la Hera A, Alvarez-Mon M. Human brucellosis is characterized by an intense Th1 profile associated with a defective monocyte function. Infect Immun. 2010;78:3272-9. 
16. Solera J, Geijo P, Largo J, Rodriguez-Zapata M, Gijon J, Martinez-Alfaro E, Navarro E, Macia MA; Grupo de Estudio de Castilla-la Mancha de Enfermedades Infecciosas. A randomized, double-blind study to assess the optimal duration of doxycycline treatment for human brucellosis. Clin Infect Dis. 2004;39:1776-82.

17. Erdogan Kayhan GE, Gul M, Kayhan B, Gedik E, Ozgul U, Kurtoglu EL, Durmus M, Ersoy MÖ. Dexmedetomidine ameliorates TNBS-induced colitis by inducing immunomodulator effect. J Surg Res. 2013;183:733-41.

18. Kayhan B, Arasli M, Eren H, Aydemir S, Kayhan B, Aktas E, Tekin I. Analysis of peripheral blood lymphocyte phenotypes and Th1/Th2 cytokines profile in the systemic immune responses of Helicobacter pylori infected individuals. Microbiol Immunol. 2008;52:531-8.

19. Goenka R, Guirnalda PD, Black SJ, Baldwin CL. B Lymphocytes provide an infection niche for Intracellular bacterium Brucella abortus. J Infect Dis. 2012;206:91-8.

20. Koçoğlu T, Kansu E, Gülmezoğlu E, Akalin E. Lymphocyte population and T lymphocyte subsets in brucellosis analyzed by monoclonal antibodies. Mikrobiyol Bul. 1986;20:221-9.

21. Kinikli S, Turkcapar N, Kucukay MB, Keskin G, Kinikli G. In vitro nonspecific mitogenic response of T-cell subsets in acute and chronic brucellosis. Diagn Microbiol Infect Dis. 2005;52:229-33.

22. Çelik I, Akbulut H. Lymphocyte subpopulations in patients with acute brucellosis. Turk J Med Sci. 2005;35:235-9.

23. Skendros P, Sarantopoulos A, Tselios K, Boura P. Chronic brucellosis patients retain low frequency of CD4+ T-lymphocytes expressing CD25 and CD28 after Escherichia coli LPS stimulation of PHA-cultured PBMCs. Clin Dev Immunol. 2008;2008:1-8.

24. Pasquali $P$, Thornton AM, Vendetti $S$, Pistoia C, Petrucci $P$, Trantino $M$, Pesciaroli M, Ruggeri F, Battistoni A, Shevach EM. CD4+CD25+ T regulatory cells limit effector T cells and favor the progression of brucellosis in BALB/C mice. Microbes Infect. 2010;12:3-10.

25. Skendros P, Boura P, Chrisagis D, Raptopoulou-Gigi M. Diminished percentage of $\mathrm{CD} 4+$ T-lymphocytes expressing interleukine-2 receptor alpha in chronic brucellosis. J Infect. 2007;54:192-7.

26. Yingst $S$, Hoover DL. T cell immunity to brucellosis. Crit Rev Microbiol. 2003;29:313-31.

27. Balwin $\mathrm{CL}$, Goenka R. Host immune responses to the intracellular bacterium Brucella: does the bacterium instruct the host to facilitate chronic infection? Crit Rev Immunol. 2006; 26:407-42.

28. Feldman KE, Loriaux PM, Saito M, Tuero I, Villaverde $H$, Siva T, Gotuzzo E, Gilman RH, Hoffmann A, Vinetz JM. Ex vivo innate immune cytokine signature of enhanced risk of relapsing brucellosis. PLOS Negl Trop Dis. 2013;7:2424.

29. Fernandes DM, Baldwin CL. Interleukin-10 downregulates protective immunity to Brucella abortus. Infect Immun. 1995;63:1130-3.

30. Rafıei A, Ardestani SK, Kariminia A, Keyhani A, Mohraz M, Amirkhani A. Dominant Th1 cytokine production in early onset of human brucellosis followed by switching towards Th2 along prolongation of disease. J Infect. 2006;53:315-24.

31. Xavier MN, Winter MG, Spees AM, Nguyen $K$, Atluri VL, Silva TM, Bäumler AJ, Müller W, Santos RL, Tsolis RM. CD4+ T cell-derived IL-10 promotes Brucella abortus persistence via modulation of macrophage function. PLOS Pathog. 2013;9:1003454.

32. de Steenwinkel JE, Knegt GJ, ten Kate MT, Verbrugh HA, Hernandez-Pando $\mathrm{R}$, Leenen PJ, Bakker-Woudenberg IA. Relapse of tuberculosis versus primary tuberculosis; course, pathogenesis and therapy in mice. Tuberculosis (Edinb). 2013;93:213-21. 